\title{
Health care for all: effective, community supported, healthcare with innovative use of telemedicine technology
}

\author{
Tariq Kazim Shah ${ }^{*}$, Tasneem Tariq ${ }^{1}$, Roger Phillips ${ }^{2}$, Steve Davison ${ }^{1}$, Adam Hoare ${ }^{3}$, Syed Shahzad Hasan² \\ and Zaheer-Ud-Din Babar ${ }^{2,4}$
}

\begin{abstract}
Almost half of the world's total population reside in rural and remote areas and a large number of these people remain deprived of most basic facilities like healthcare and education. It is deemed impossible for government with scarce resources in developing countries to open and run a health facility in every remote community using conventional means. One increasingly popular unconventional mean is the use of existing technology to improve exchange of medical information for the purpose of improving health of underprivileged communities.

Telemedicine implies the use of information and communication technology to provide health care remotely from a distance. With the induction of telemedicine, patients who live in rural and remote areas can have increased access to medical services. In many developing countries, use of telemedicine however has been limited mainly to teleconferencing between primary and secondary/tertiary care facilities for diagnosis and management of patients. This system still requires patients from remote communities to travel, often long and arduous journeys to the centre where telecom and medical facilities are available. Health Care 4 All International, a not for profit registered charity is providing primary care to patients by taking telemedicine into their homes in remote communities, thus obviating the need and hardships of travel for patient.
\end{abstract}

Keywords: Primary, Healthcare, Remote rural communities, Telecommunication, Technology, Innovation, Telemedicine

\section{Introduction}

In 2015, United Nations published a report about the achievements of the Millennium Development Goals (MDGs) for the past 15 years. Although 'dramatic progress' has been made and all MDG's influence health $[1,2]$, there still exists inequalities in healthcare provision between the high and low income countries. There are also stark differences between the urban and rural population. United Nations Department of Economics \& Social Affairs highlighted that there is about a 50:50 divide between the urban and rural population yet only $26 \%$ of world's medical doctors and $32 \%$ of the world's nurses provide healthcare services in the rural areas [3-5]. Almost all (99\%) of both child and maternal mortality occur in the low and middle-

\footnotetext{
* Correspondence: healthcare4all@outlook.com

${ }^{1}$ Health Care 4 All International, Willow House 107 All Alone Road Bradford, Bradford, West Yorkshire BD10 8TR, UK

Full list of author information is available at the end of the article
}

income countries and are highest in the rural communities $[6,7]$.

Information and Communication technology (ICT) has shown huge potential to overcome public health challenges and in this context, telemedicine can play an important role. Telemedicine is the use of ICT to provide clinical health care from a distance. It has been used to overcome distance barriers and to improve access to medical services. Access, equity, quality, and cost-effectiveness are key issues facing healthcare in both developed and less economically developed countries [8].

Conventional telemedicine requires a fast and reliable telecommunication network, and both the service user and provider to have telecommunication equipment and the knowledge to use them. This is very challenging in the developing countries, particularly in the remote rural communities. Cost also prohibits the use of telemedicine in its conventional form. In this context, a new model is 
being developed to promote safe and cost-effective use of these resources in a low-income country setting. In this editorial, we discuss about the use and functioning of this model.

Health Care 4. All International (HC4AI) is a not for profit registered charity that has innovated and modified Telemedicine to suit the environment prevailing in the selected area of deployment. We call this Novel Hybrid System of Telemedicine' (NHST). HC4AI has been providing healthcare successfully for over three years in the villages of Kashmir in Pakistan. In this editorial, we present how NHST works and our experience.

\section{HC4Al solution: Novel Hybrid System of Telemedicine}

We selected four men and four women from these villages with some paramedical background, trained them in basic use of technology and updated on routine and emergency medical practice. They were then provided with computer tablets downloaded with our own developed Electronic Health Record (EHR) software and located them in a central place (Monitoring Centre) from where they can reach any household in the village when called. These 'Community Health Workers' (CHW) became the mouthpiece for the community-an interface between the patient in their homes and the doctor located remotely. They provided a round the clock service. They also carry a 'tool bag' containing diagnostic equipment, first aid kit, set of routinely used medicines and a portable telecommunication antenna.

As no suitable bandwidth was available in the area, we established our own telecommunication network with the help of Mirpur University of Science and Technology [9] Every individual in the community is registered with a unique ID number, entered on EHR with medical history and provided with a single telephone number to call whenever they need medical help. We also acquired two ambulances equipped with a communicating antenna, and two salaried doctors, a male and a female, to work $24 \mathrm{~h}$ on-call schedule in tandem. Specialists who agreed to provide service voluntarily or for a fees per case basis were also appointed covering the mainline specialities of medicine, surgery, paediatrics, obstetrics \& gynaecology and orthopaedics. The project was started in 2014 as a pilot study covering a population of 1500 spread in eight small villages. However with rapid success, it was converted into a full service in early 2015 . It has since gradually expanded into surrounding villages at minimal extra cost and now covers a population of nearly 50,000 inhabitants spread over in more than thirty villages.

\section{How does the system work}

When a call is received at the monitoring centre the oncall CHW team goes to the caller in the ambulance, if the terrain is inaccessible to the ambulance, the CHW have to walk. After noting the history and examination on the EHR, the CHW contacts the doctor via video/audio link, who can interview the patient directly if required. The doctor then makes the diagnosis and suggests treatment; the $\mathrm{CHW}$ dispenses the medicine to the patient. More serious patients are evacuated in the same ambulance to the base and if specialist care is required, then the patient is transferred to the specialist centre. Every step of the patients' journey is recorded on the EHR as well as on the central database. An evaluation of the service, (Pre- and PostNHST Intervention) of 350 households shows extremely positive experience especially in the provision of health services, access to medical care and advice to the family.

\section{Concluding remarks}

We believe that the success of the model depends on building on a local approach. The cultural and religious beliefs need to be understood and should be kept in perspective when designing these services. Also, the success depends on having a strong base in the community. This is also vital in the context, to identify the needs, acceptance and ownership of these services. Another take home lesson is that as much as possible, the workforce should be selected from these communities.

\section{Acknowledgements \\ None \\ Funding \\ None.}

\section{Authors' contributions}

All authors participated in the drafting and revision of the manuscript, as well as in editing and soliciting specific articles cited here. All authors read and approved the final manuscript.

\section{Authors' information}

Tariq Kazim Shah MBBS. LRCP MMEd FRCS is a Consultant Urological Surgeon in UK and Founder Chairman of the charity 'Health Care 4 All International'.

Tasneem Tariq MBBS. Med (Dip) FRCOG is a consultant Obstetrician and Gynaecologist and Vice Chairperson of the charity 'Health Care 4 All International'.

Roger Phillips, PhD Professor of Cancer Pharmacology at the Department of Pharmacy, University of Huddersfield HD1 3DH, Huddersfield United Kingdom.

Steve Davison, QDR, B Nurs, RGN, RMN, HV (Cert), NDN (cert). As both a qualified nurse and MBA qualified commercial mediator.

Adam Hoare Ph.D., MBA, B.Sc., B.Sc., C.Phys., MIEEE, MIOP, MIET, Executive Director of Sociotechnical Systems at The Bayswater Institute, Honorary Visiting Research Fellow at University of Bradford Faculty of Health Studies. Syed Shahzad Hasan, PhD is a Research Fellow at the Department of Pharmacy, University of Huddersfield HD1 3DH, Huddersfield United Kingdom.

Zaheer-Ud-Din Babar, PhD is a Professor in Medicines and Healthcare at the Department of Pharmacy, University of Huddersfield HD1 3DH, Huddersfield United Kingdom.

Ethics approval and consent to participate Not Applicable.

Consent for publication

All authors approved the manuscript. 


\section{Competing interests}

TS and TT have largely funded the charity Health Care 4 All through their own philanthropy. The charity has also received donations from a number of individual donors. Their interest is purely philanthropic and they do not have any financial benefit from it.

$\mathrm{AH}, \mathrm{SD}, \mathrm{RP}, \mathrm{SS}$ no competing interest declared.

ZUDB is the Editor in Chief of Journal of Pharmaceutical Policy and Practice.

\section{Publisher's Note}

Springer Nature remains neutral with regard to jurisdictional claims in published maps and institutional affiliations.

\section{Author details}

${ }^{1}$ Health Care 4 All International, Willow House 107 All Alone Road Bradford, Bradford, West Yorkshire BD10 8TR, UK. ${ }^{2}$ Department of Pharmacy, School of Applied Sciences, University of Huddersfield, Huddersfield HD1 3DH, UK. ${ }^{3}$ Bayswater Institute, 9 Orme Court, London W2 4RL, UK. ${ }^{4}$ School of Pharmacy, Faculty of Medical and Health Sciences, University of Auckland, Auckland Private Mail Bag 92019, New Zealand.

Received: 11 January 2018 Accepted: 12 January 2018

\section{Published online: 01 February 2018}

\section{References}

1. Millennium development Goals Report 2015. un.org http://www.un.org/ millenniumgoals/2015 MDG Report/pdf/ MDG\%202015\%20rev\%20(July\%201).pdf (accessed 8 Jan 2018).

2. Millennium Development Goals (MDG): un.org http://www.who.int/topics/ millennium_development_goals/about/en/ (accessed 8 Jan 2018).

3. Lehmann U, Dieleman M, Martineau T. Staffing remote rural areas in middle-and low-income countries: a literature review of attraction and retention. BMC Health Serv Res. 2008:8:19.

4. Dussault G, Franceschini MC. Not enough there, too many here: understanding geographical imbalances in the distribution of the health workforce. Hum Resour Health. 2006;:1-12. https:/doi.org/10.1186/1478-4491-4-12.

5. Increasing access to health workers in remote and rural areas through improved retention: global policy recommendations. Geneva: World Health Organization 2010; http://www.who.int/hrh/retention/guidelines/en/ (accessed 9 Jan 2018).

6. Lawn JE, Cousens S. Zupan J, for the lancet neonatal survival steering team: million neonatal deaths: when? Where? Why? Lancet. 2005;365(9462):891-900.

7. WHO Media Centre info: http://www.who.int/mediacentre/factsheets/fs348/ en/ (accessed 8 Jan 2018).

8. Telemedicine - Opportunities and developments in member states. WHO Global Observatory eHealth Series Vol.2. http://www.who.int/goe/ publications/goe telemedicine 2010.pdf (accessed 8 Jan 2018).

9. Department of Computer systems engineering and Telecommunication; Mirpur University of Science and Technology. Mirpur AJK Pakistan. http:// www.must.edu.pk/engineering/CSE/program.html (accessed 8 Jan 2018).

\section{Submit your next manuscript to BioMed Central and we will help you at every step:}

- We accept pre-submission inquiries

- Our selector tool helps you to find the most relevant journal

- We provide round the clock customer support

- Convenient online submission

- Thorough peer review

- Inclusion in PubMed and all major indexing services

- Maximum visibility for your research

Submit your manuscript at www.biomedcentral.com/submit
Biomed Central 